One of the most interesting mineral elements, in its behaviour in the animal body, is manganese. Rats given a diet deficient in manganese were unable to suckle their young, and they showed no normal maternal instincts. Many of the neglected young rats died within a few hours. Deficiency of manganese in chickens produces a condition known as 'slipped tendon', or perosis, in which the angle joint is displaced and the birds crippled so badly they usually die. Hens deficient in manganese lay eggs of very low hatchability, many of the chicks dying in the shell a few days before the time for hatehing. These embryos are often deformed, having short, thickened leg and wing bones and globular heads. When manganese is injected into hens deficient in the mineral the eggs hatch normally and produce chicks with normal bones. At present there is no evidence concerning the occurrence of manganese deficiency in human beings.

Reference was also made by Prof. McCollum to the demonstration of cobalt deficiency as the cause of a blood disease in sheep and cattle known variously throughout the world as 'Denmark disease', 'coast disease', the 'pines', 'bush sickness', and 'salt sick'. The animals suffering from the disease were found to have been grazing on pastures the soil of which was deficient in cobalt. The investigations which proved the point constitute one of the classics of nutritional research. This disease, it will be recalled, has been the topic of articles and correspondence in NATURE during recent years.

\title{
AFFINITIES IN THE PUEBLO CULTURE OF ARIZONA*
}

$\mathrm{D}^{\mathrm{n}}$ . FRANK H. H. ROBERTS, JUN., continues his report on his archæological excavations of the Whitewater Anasazi or Basket-Maker-Pueblo remains in Eastern Arizona (see NaTuRE, 144, 556; 1939) by an account of the pottery, and objects of bone, stone and shell which were found, as well as of the burials which were examined. From the burials skeletal remains of 150 individuals were discovered, but of these 15 only were sufficiently well preserved to permit of recovery, examination and report.

The objects recovered by the investigation permit of a very partial view only of the material culture of the inhabitants. Virtually the whole of the products of their industry made of perishable material is missing. A few potsherds bear the impress of basketry, while a few charred pieces of cord were found. The basketry was of the characteristic coiled form. There is no evidence of clothing, textiles or wooden imple. ments, though these must have played a large part in their lives.

The specimens collected were found in the remains of houses, in the various refuse mounds, as offerings accompanying burials, in a few instances on the old occupation surface near dwellings and outside firepits. No articles appear to have been made specially for funerary purposes.

Most of the artefacts represent one stage, the Developmental Pueblo, though there are a few from the earlier stage, the Modified Basket:Maker, and the later, the Great Pueblo. Dated timbers from the various structures indicate datings ranging from the early part of the ninth century to the early years of the eleventh century A.D. Pottery sequences have been checked and confirmed by stratigraphic evidence.

True pottery first appears in the Anasazi province in the Modified Basket-Maker stage. Vessels were occasionally made of unfired clay tempered with shredded cedar bark or grass, the prototype of the later makes that came to play so prominent a part in the life and industry of the people. In some

* Smithsonian Institution, Bureau of American Ethnology, Bull. 126. Archæological Remains in the Whitewater District, Eastern Arizona. Pt. 2. Artifacts and Burials. By Frank H. H. Roberts, Jr. With an appendix: Skeletal Remains from the Whitewater District, Eastern Arizona. By T. D. Stewart. Pp. xi $+170+57$ plates. (Washington, D.C.: G.P.O.) 50 cents. instances the bottoms were moulded in baskets, the walls or rims being formed of fillets of clay looped around the upper edges. Others were fashioned entirely by hand without basal support by a coiling process. The principal shapes were shallow trays and deep bowls. The unfired clay objects may be attributed to influences from regions to the south but the methods used seem to have been mainly indigenous, since the Basket-Makers were already adepts in the use of clay for architectural purposes, as for example in the jug-like necks of the tops of their granaries and the mud steps placed on granary walls. When firing of clay developed, the cedar bark binder was replaced by sand, which in turn was gradually replaced by powdered rock, and this in the Developmental Pueblo period by ground potsherds.

The Modified Basket-Maker phase had developed a variety of shapes in its pottery, while protruding particles in the paste gave it a characteristic irregularly stippled appearance. Decoration for the most part was confined to the interior of bowls and was produced by the use of carbon which was prevalent in north-eastern Arizona, and an iron, which was widely distributed over the remainder of the area. The designs are generally ribbon-like panels embellished with dots, zig-zags, and stepped line elements. The opening of the Developmental Pueblo period witnessed changes. New features were introduced and there was a marked expansion in the industry. Surfaces were carefully smoothed and the application of a step was introduced. A great diversity of form is shown with colour; plain grey, black on white, black on red, and brown with a brownish exterior and a slightly burnished interior. All types of vessel are decorated. There are two main groups of the light-coloured vessels ornamented with black, of which one occurs throughout the eastern part of Arizona centring about the Chaco Canyon area, and the other predominating in the west.

On the Whitewater site, stratigraphic tests show a definite progression in pottery forms and a certain sequence in the appearance of types. This is augmented by the association between ceramic styles and house remains and an indication of a certain 
time factor through the dendrochronological dating of some of the structures. The earliest type of pottery noted for the district is a form identifiable as late Modified Basket-Maker of the eastern variety-a type oceurring across the plateau in western New Mexico to the San Juan and into the north-eastern San Juan basin. The second type in the series is one typical of the beginning stage of the Developmental Pueblo period through the greater part of the Anasazi province that was characterized by the Chaco cultural pattern. Afterwards, a new form appeared that gives strong evidence of Chaco influence but which seemingly comes from the area lying between the Puerco and Little Colorado Rivers - the Little Colorado style as it has been called. While this ware indicates an affinity with types found along the Little Colorado, the designs suggest a Chaco derivation. A third type of the Early Developmental Pueblo is the Kana-a black on white. Most of the ceramic developments during middle and late phases of the Whitewater occupation were an outgrowth from these three forms with some additions from the Little Colorado, the Upper Gila of New Mexico, and continued influence from the Chaco Canyon area in north-western New Mexico.

The significant feature about the pottery evidence is that it demonstrates an early south-west extension of influence from the Chaco Canyon area with a spread later toward the north-west from Little Colorado centres and towards the south-east from the Kayenta or Tusayan region--a movement contrary to that postulated by many south-western workers and tending to show that many traits appear in the Chaco that have been attributed to influence penetrating from the Little Colorado region, though they belong to the Chaco and were diffused from there towards the Little Colorado. Further, from evidence of the present material, there must have been a strong interplay of influence between the Chaco and Tularosa regions before the growth of that between Tularosa and Little Colorado.

Although the skeletal material examined by Dr. Stewart is not sufficient to give a broad viow of the general characteristics of the people, certain interesting and important points emerge.

In the first place, further elaboration is given to Seltzer's view that the evidence does not justify the theory of a sweeping change in physical type during the transitional Basket-Maker-Pueblo period. This theory rests chiefly upon the unproved premise that cranial deformation among the Pueblos is accidental, but the predominance of lambdoid deformation in the Whitewater District and among the culturally related groups in New Mexico and Colorado lends force to the view that in general its use among the Pueblos was more than accidental, thus effectively masking the long-headed form of the natural skull. The evidence thus runs contrary to the generally accepted view that the beginning of the Pueblo period was marked by an infiltration of round-headed groups.

Secondly, the present group shows definite relationship to the Basket-Maker physical type as well as to other peoples having the Anasazi cultural pattern, the so-called "South West Plateau" physical type. Further, according to Dr. Stewart the 'lambdoid' type of deformation points to a relationship with peoples who occupied certain sites in the Chaco Canyon and south-western Colorado, "a feature which correlates nicely with the cultural evidence for a predominant Chaco influence in the [Whitewater] arts and industries".

\section{FORTHCOMING EVENTS}

\author{
Monday, November $x 8$
}

Royal Society of Arts (at John Adam Street, Adelphi, London, W.C.2), at 1.45 p.m.-Prof. S. J. Davies: "Recent Developments in Internal Combustion Engines" (Cantor Lectures, 1).

Royal Geographical Society (at Kensington Gore, London, S.W.7), at 3 p.m.-Miss Harriet Wanklyn: "The Rôle of Peasant Hungary in Europe".

Tuesday, November 19

Institution of Civil Enginears (at Great George Street, S.W.1), at 1.30 p.m.-Mr. William Barnes: "Methods of Excavation Work at Home and Abroad" (Dugald Clerk Lecture).

\section{APPOINTMENTS VACANT}

Applicatrons are invited for the following appointments on or before the dates mentioned:

HEAD OF THE ENGINEERING DEPARTMENT OF THE SMETHWICK MUNICIPAL COLTEGE-The Chief Education Officer, Education Offices, 215 High Street, Smethwick (November 21).

ENGINEERING WORKSHOP INSTRUOTOR-The Principal, Twickenham Technical College, Egerton Road, Twickenham (November 23).

assistant Mechanical Enginegr for the Electrical Branch, Public Works Department of the Government of Nigeria--The Crown
Agents for the Colonies, 4 Millbank, London, S.W.1 (quoting M/9346).

\section{REPORTS AND OTHER PUBLICATIONS}

(not included in the monthly Books Supplement)

\section{Great Britain and Ireland}

British Electrical and Allied Industries Research Association. Technical Report, Reference W/T2: A Critical Study of the Application of Electricity to Agriculture and Horticulture. By C. A. Cameron Brown. Pp. 84. (London: British Electrical and Allied Industries Research Association:) 28. net. [3010

London Shellac Research Bureau. Bulletin No. 4: Chemical Constants of Lac-Some Notes on the Acid, Saponiflcation and Hydroxyl Values of Lac. By Dr. B. S. Gidvani and Mrs. J. M. Dobbie. Pp.
16. (London: London Shellac Research Bureau.)

\section{Other Countries}

Queen Victoria Memorial, Salisbury, Southern Rhodesia. Annual Report for the Year ended 31st March 1940. Pp. 8. (Salisbury: Queen Victoria Memorial.)
[2210

Colony and Protectorate of Kenya. Forest Department Annual Report, 1939. Pp. 30. (Nairobi : Government Printer.) 2s. [2210 Statens Meteorologisk-Hydrografiska Anstalt. Årsbok, 19, 1937. iv. Meteorologiska iakttagelser i Sverige, Band 79. Pp. xi $+107.7 \mathrm{kr}$. Ársbok, 21, 1939. i. Mănadsöversikt över väderlek och vattentillgång. Pp. 78. $2.50 \mathrm{kr}$. Meddelanden, Band 7, No. 6: Temperaturmätningar i Vănern och Götaălv. Av Anders Angström och Stig Jacobson. Pp. $20+12$ plates. $2.50 \mathrm{kr}$. (Stockholm: Statens MeteorologiskHydrograflska Anstalt.)

$[2310$

Smithsonian Institution : Bureau of American Ethnology. Bulletin 126: Archæological Remains in the Whitewater District, Eastern Arizona. Part 2: Artifacts and Burials. By Frank H. H. Roberts, Arizona. Part 2: Artifacts and Burials. By Frank $H$. H. Roberts, District, Eastern pendix , Skeletal Remains from the Whitewater (Washington, D.C.: Government Printing Office.) 50 cents. [2510 Pennsylvania State College: School of Agriculture and Experiment Station. Bulletin 391: The Utilization of Certain Feeding Stuffs by Cattle. By E. B. Forbes, John W. Bratzler and Cyrus E. French. Pp. ii +14. (State College, Pa.: Pennsylvania State College.)

Proceedings of the American Philosophical Society, Vol 83, 4: Symposium on Characteristics of A merican Culture and its, in General Culture. Pp. 513-588. (Philadelphia: American Philo-
sophical Society.) 50 cents.

Proceedings of the United States National Museum. Yol. 89, No 3094: The West American Haliotis. By Paul Bartsch. Pp. 49-58 plates 6-8. (Washington, D.C. : Government Printing Office.) [2910 Royal Observatory, Hong Kong. Meteorological Results, 1939, prepared under the direction of C. W. Jeffries. Pp. $v+144+40+6$. 3 dollars. Annual Report of the Director of the Royal Observatory Hong Kong, for the Year 1939. Pp. F8. 30 cents. (Hong Kong Government Printers.)

Report of the Kodaikanal Observatory for the Year 1939 Pp. (Delhi : Manager of Publications.) 2 annas ; $3 d$. 